\title{
Antiproliferative and Proapoptotic Activities of Methanolic Extracts from Ligustrum vulgare $L$. as an Individual Treatment and in Combination with Palladium Complex
}

\author{
Milena G. Ćurčić ${ }^{1, *}$, Milan S. Stanković ${ }^{1}$, Emina M. Mrkalić ${ }^{2}$, Zoran D. Matović ${ }^{2}$, \\ Dragić D. Banković ${ }^{3}$, Danijela M. Cvetković ${ }^{1}$, Dragana S. Đačić ${ }^{1}$ and Snežana D. Marković ${ }^{1}$ \\ 1 Department of Biology and Ecology, Faculty of Science, University of Kragujevac, Radoja \\ Domanovića 12, 34000 Kragujevac, Republic of Serbia; E-Mails: mstankovic@kg.ac.rs (M.S.S.); \\ c_danijela@yahoo.com (D.M.C.); draganadjacic@kg.ac.rs (D.S.D.); smarkovic@kg.ac.rs (S.D.M.) \\ 2 Department of Chemistry, Faculty of Science, University of Kragujevac, Radoja Domanovića 12, 34000 \\ Kragujevac, Republic of Serbia; E-Mails: emrkalic@kg.ac.rs (E.M.M.); zmatovic@kg.ac.rs (Z.D.M.) \\ 3 Department of Mathematics, Faculty of Science, University of Kragujevac, Radoja Domanovića 12, \\ 34000 Kragujevac, Republic of Serbia; E-Mails: dragic@kg.ac.rs (D.D.B.)
}

* Author to whom correspondence should be addressed; E-Mail: milenacurcic@kg.ac.rs; Tel.: +381-34-336-223; Fax: +381-34-335-040.

Received: 27 December 2011; in revised form: 23 January 2012 / Accepted: 15 February 2012 / Published: 22 February 2012

\begin{abstract}
The aim of this study is to examine the growth inhibitory effects of methanolic leaf and fruit extracts of $L$. vulgare on HCT-116 cells over different time periods and their synergistic effect with a $\mathrm{Pd}($ apox) complex. The antiproliferative activity of plant extracts alone or in combination with the $\operatorname{Pd}($ apox) complex was determined using MTT cell viability assay, where the $\mathrm{IC}_{50}$ value was used as a parameter of cytotoxicity. Results show that antiproliferative effects of $L$. vulgare extracts increase with extension of exposure time, with decreasing $\mathrm{IC}_{50}$ values, except for $72 \mathrm{~h}$ where the $\mathrm{IC}_{50}$ values for methanolic leaf extract were lower than for the fruit extract. The $\operatorname{Pd}($ apox) complex alone had a weak antiproliferative effect, but combination with $L$. vulgare extracts caused stronger effects with lower $\mathrm{IC}_{50}$ values than with $L$. vulgare extracts alone. The type of cell death was explored by fluorescence microscopy using the acridin orange/ethidium bromide method. Treatments with plant extracts caused typical apoptotic morphological changes in HCT-116 cells and co-treatments with Pd(apox) complex caused higher levels of apoptotic cells than treatment with plant extracts alone. The results indicate that $L$. vulgare is a
\end{abstract}


considerable source of natural bioactive substances with antiproliferative activity on HCT-116 cells and which have a substantial synergistic effect with the $\operatorname{Pd}($ apox) complex.

Keywords: acridin orange/ethidium bromide assay; antiprolifertative activity; apoptosis; cotreatment; Ligustrum vulgare L.; MTT assay; palladium; time dependance

\section{Introduction}

Wild privet, Ligustrum vulgare L. (Oleaceae) is a semi-evergreen woody branched bush, growing to $5 \mathrm{~m}$ tall. The stems are stiff, erect and with grey-brown spotted bark; leaves are lanceolate or broadly elliptical, $2-7 \mathrm{~cm}$ long and $0.5-2 \mathrm{~cm}$ broad. The flowers are white and fragrant, forming a pyramidal panicle. The fruit is a small glossy black berry of 6-8 $\mathrm{mm}$ diameter, containing one to four seeds. It usually inhabits forest ecosystems of Central and Southern Europe, North Africa and Southwest Asia, and is often cultivated as an ornamental plant [1].

Leaves of $L$. vulgare are used for disease prevention or treatment in folk medicine in southern Europe [2], mostly because of their immunomodulatory [3], cardioprotective [4], antibacterial [5], antidiabetic effects [6], and it has also been found that different leaf and fruit extracts of this plant can scavenge $\mathrm{OH}$ and DPPH radicals [7]. From the traditional uses and later scientific findings, which suggested cytotoxic activity against HeLa cells [8], L. vulgare may be a potential candidate as an antiproliferative agent against cancer cell lines. Different in vitro assays performed in L. vulgare leaves show broad pharmacological potential of this plant due to the presence of flavonoids, phenylpropanoids and terpenoids (mainly secoiridoids) [2,9]. However, there is no data available on the antiproliferative activity of $L$. vulgare fruit extracts.

Nature has long been an important source of medicinal agents. An impressive number of modern drugs have been isolated or derived from natural sources, based on their use in traditional medicine [10,11]. Ethnopharmacological or traditional use of plants often results in the discovery of new biologically active molecules [12]. A wide variety of secondary metabolites obtained from plants are tested for their ability to treat cancer. Various plant-derived anti-cancer drugs are known to be effective against proliferating cells. In addition, there are chemotherapeutic compounds commonly used to fight cancer, such as cisplatin [13]. Although cisplatin is a valuable antitumor drug, it has several disadvantages including side effects such as nephrotoxicity, ototoxicity, neurotoxicity, myelotoxicity, peripheral neuropathy and hematological toxicity [14]. The adverse effects observed in patients receiving cisplatin chemotherapy have generated new areas of research mainly focused on the search for new nonplatinum metal-based complexes displaying low toxicity with improved therapeutic properties. A new $[\mathrm{Pd}(\operatorname{apox})]$ complex was synthesized in an attempt to obtain compounds with superior chemotherapeutic index in terms of increased bioavailability, higher cytotoxicity, and lower side effects than cisplatin. The coordination chemistry of palladium(II) is very similar to that of platinum(II), but the higher lability in ligand exchange at the Pd centre ( $10^{5}$-fold vs. Pt) may cause rapid hydrolysis processes leading to the dissociation of the complex and formation of very reactive species unable to reach their biological targets. This issue could be overcome by using bulky heterocyclic and chelating ligands. Here we used the chelating ligand $\mathrm{H}_{2}$ apox $\left(N, N^{\prime}\right.$-bis(3- 
aminopropyl)oxamido) to synthesize a neutral $N, N$ '-bis(3-aminopropyl)oxamido palladium(II) complex. In the equatorial plane, the complex contains fully deprotonated bidentate ligands capable of forming a five-membered (oxamido) backbone.

The aim of this study is to examine the growth inhibitory effects of methanolic leaf and fruit extracts of L. vulgare, on human colon cancer cells (HCT-116) over different time periods by two different assays along with their synergistic effect with $\operatorname{Pd}($ apox) complex, as well as to examine the type of cell death.

\section{Results and Discussion}

\subsection{Time- and Dose-Dependent Effects of L. vulgare Extracts on Cell Proliferation}

We conducted two in vitro experiments on human colon cancer cells-HCT-116 cell line. The MTT cell viability assay in vitro is the primary stage for screening. Cells were treated with different concentrations of plant extracts (in concentration range from 1 to $500 \mu \mathrm{g} / \mathrm{mL}$ ) at different duration ranges $(3,6,12,24,48$ or $72 \mathrm{~h})$ to clarify the role of the time of exposure. Figure 1 shows the dose and time-dependent activity of extracts for all duration ranges. We chose different incubation times to determine the most effective one. While the inhibition of cell viability was obtained after $3 \mathrm{~h}$ of treatment only for the highest concentrations, prolonged treatments $(6,12,24$ and $72 \mathrm{~h})$ caused significant inhibition of viability for all concentrations. The anti-proliferative activity of the L. vulgare extracts depended on the exposure time. However, the cell proliferation at $72 \mathrm{~h}$ treatment resulted in an increase in $\mathrm{IC}_{50}$ values (inhibitory dose inhibited cell growth by $50 \%$ ). A significant time-dependent inhibition of cell proliferation was not obtained when only exposing the cells to the lower concentrations after $72 \mathrm{~h}$, and this did not strengthen along with the longer time of exposure. Low concentrations can kill cells immediately after treatment, but after longer time of exposure, cells recover and they can stimulate some proliferative effects in surviving cells. This correlates with the previously obtained results with HCT-116 cell line [15].

Table 1 presents in vitro cytotoxic activities of the methanolic extracts of L. vulgare, which were expressed by $\mathrm{IC}_{50}$ values. The $\mathrm{IC}_{50}$ value was used as a parameter for cytotoxicity. The results showed that maximum effect has methanolic leaf extract after $24 \mathrm{~h}(28.2 \mu \mathrm{g} / \mathrm{mL})$, indicating this time as the most effective time exposure for antiproliferative effects.

Table 1. Growth inhibitory effects - $\mathrm{IC}_{50}$ values $(\mu \mathrm{g} / \mathrm{mL})$ of methanolic leaf and fruit extracts of $L$. vulgare on HCT-116 cell line after 3, 6, 12, 24 and $72 \mathrm{~h}$ of treatment.

\begin{tabular}{cccccc}
\hline $\begin{array}{c}\text { Methanolic extracts } \\
\text { of } \boldsymbol{L} \text {. vulgare }\end{array}$ & After $\mathbf{3 ~ h}$ & After $\mathbf{6 ~ h}$ & After $\mathbf{~ 2 ~ h ~}$ & After $\mathbf{2 4} \mathbf{~ h}$ & After 72 h \\
\hline $\begin{array}{c}\text { leaf } \\
\text { fruit }\end{array}$ & $>500$ & $159.5 \pm 1.92$ & $147.8 \pm 7.29$ & $28.2 \pm 0.76$ & $64.6 \pm 3.84$ \\
& $>500$ & $325.9 \pm 4.51$ & $240.8 \pm 3.64$ & $47.4 \pm 3.54$ & $108.0 \pm 5.32$ \\
\hline
\end{tabular}


Figure 1. Effects of methanolic leaf extract (1) and fruit extract (2) of L.vulgare on HCT-116 cell proliferation. The cells were treated with various concentrations of extracts and antiproliferative activities were measured by MTT assay after 3, 6, 12, 24 and $72 \mathrm{~h}$ of treatment. Results were expressed as means \pm SE for three independent determinations.

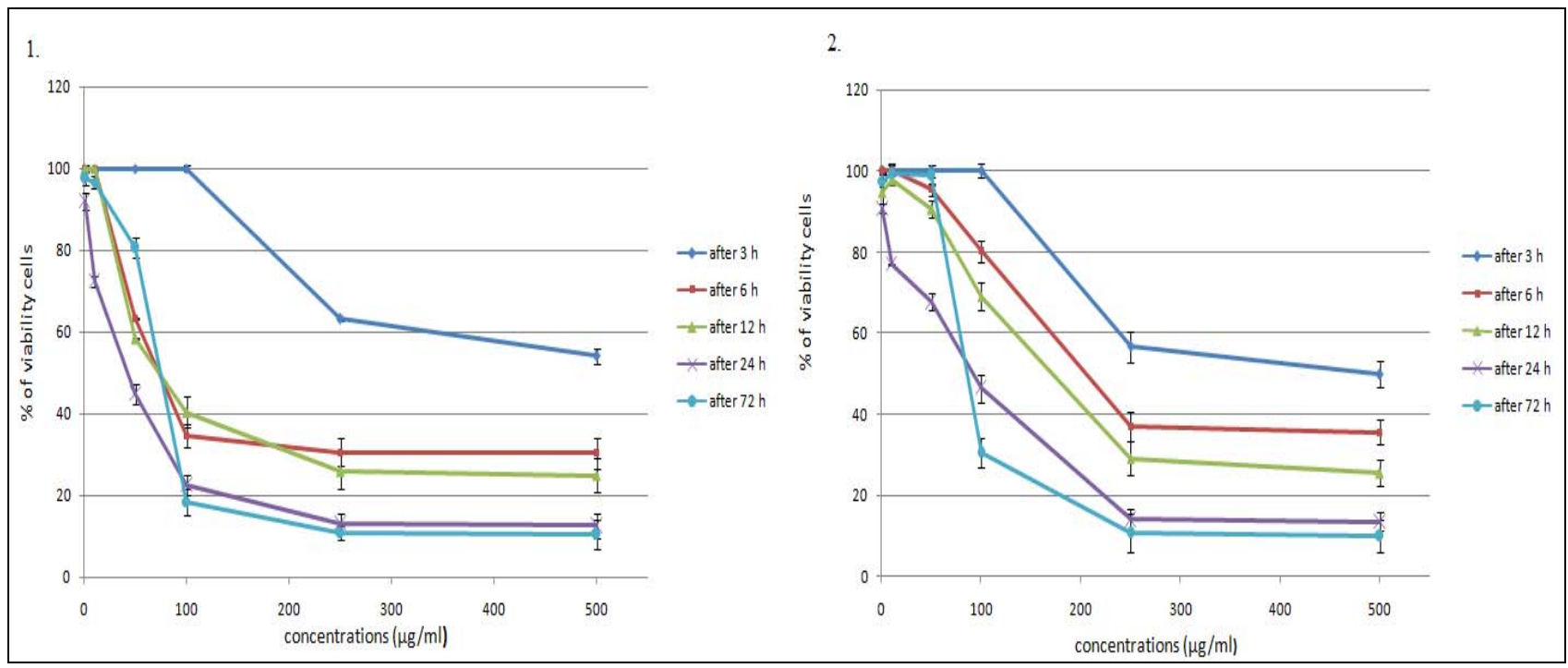

Natural bioactive substances can modify redox status and interfere with basic cellular functions (cell cycle, apoptosis, inflammation, angiogenesis, invasion and metastasis) [16]. Apoptosis is important in embryological development, cell proliferation, cell differentiation, elimination of seriously damaged cells or tumor cells by chemopreventive or chemotherapeutic agents and many other physiological processes [17]. Apoptotic cells and bodies are rapidly recognized by macrophages before cell lysis, and then can be removed without inducing inflammation. Therefore, the induction of apoptosis is an important mechanism of chemoprevention and chemotherapy of cancer. To determine whether the inhibition of cell proliferation by methanolic extracts from L. vulgare was due to the induction of apoptosis, we assessed the latter with the acridine orange/ethidium bromide method. Proapoptotic activity of methanolic extracts from L. vulgare was investigated with respect to the morphological shape of cells by fluorescence microscopy. Fluorescence microscopy images clearly showed morphological changes such as reduction in size and cell volume, cell shrinkage, membrane blebbing, chromatin condensation, nuclear fragmentation and formation of apoptotic bodies of treated cells (Figure 2).

Table 2 summarizes the results obtained with $\mathrm{AO} / \mathrm{EB}$ double staining. The percentages of viable, apoptotic and necrotic cells were noted for different incubation periods with extracts (Table 1). Typical morphological changes after different time periods are shown on Figure 2. A time dependent increase in induction of apoptosis was also observed, except for $72 \mathrm{~h}$ treatment, which was also apparent in the results from the MTT assay. Compared with spontaneous apoptosis observed in control cells, HCT-116 treated with $100 \mu \mathrm{g} / \mathrm{mL}$ methanolic extracts of L. vulgare showed increased percentages of early apoptotic cells (the higest increase showed methanolic leaf extract of L. vulgare: $45.7 \%$, after $24 \mathrm{~h}$ ), and increased percentages of necrotic cells (the highest increase showed methanolic fruit extract of L. vulgare: $3.1 \%$, after $72 \mathrm{~h}$ ). 
Figure 2. Typical morphological changes of HCT-116 cells induced by $100 \mu \mathrm{g} / \mathrm{mL}$ methanolic extracts of $L$. vulgare, stained with AO/EB. The images were taken using fluorescence microscopy at 400×. C: control, no treated cells; MB: membrane blebbing; CC: chromatin condensation; EA: early apoptosis; LA: late apoptosis; AB: apoptotic body; $\mathrm{N}$ : necrosis.

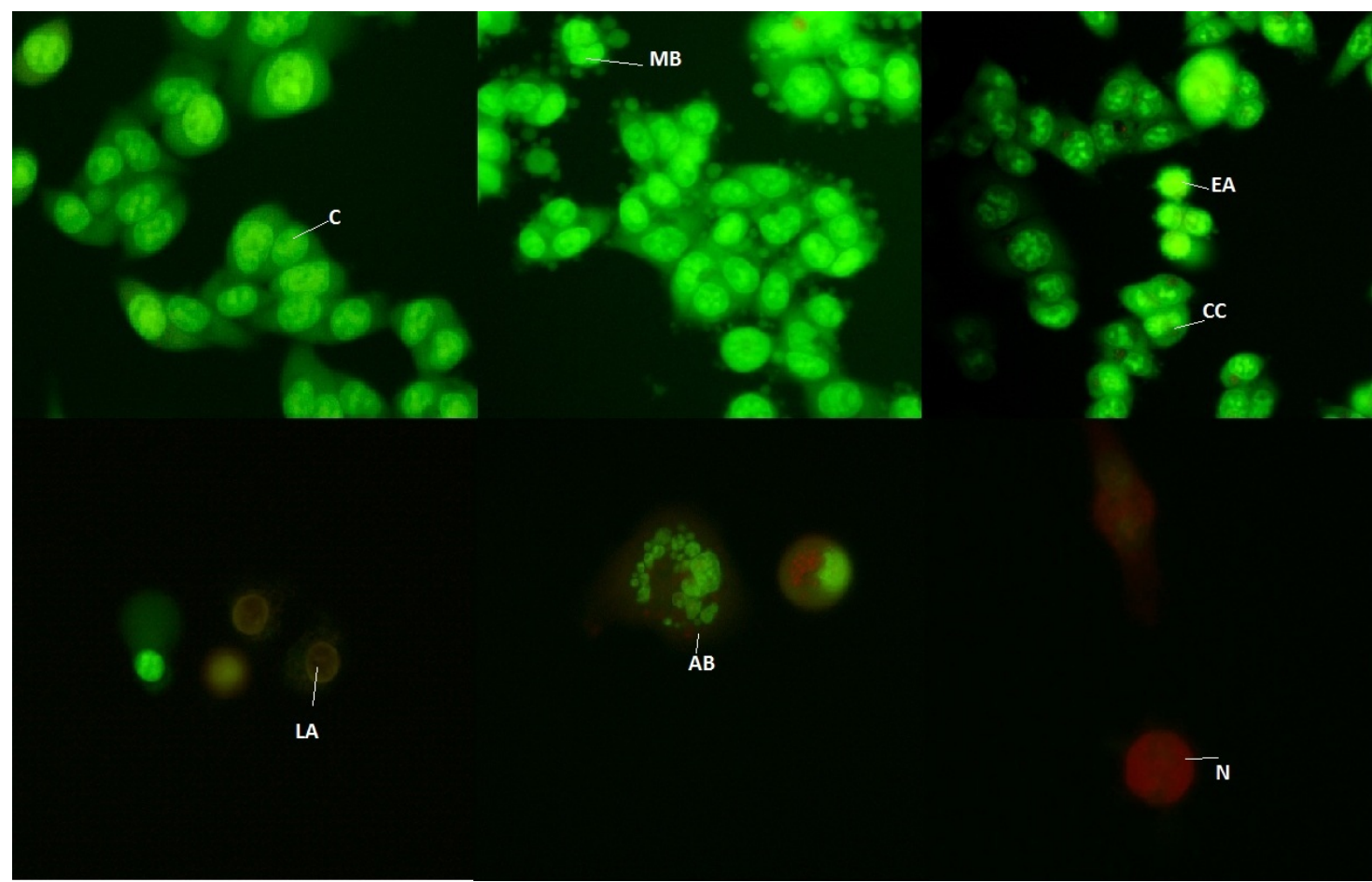

Table 2. Different values of viable, apoptotic and necrotic cells as percentage of all cells, measured by $\mathrm{AO} / \mathrm{EB}$ fluorescence staining, after treatment by $100 \mu \mathrm{g} / \mathrm{mL}$ of methanolic extracts of L. vulgare. The percentages of cells were measured after 3, 6, 12, 24 and $72 \mathrm{~h}$ of treatment. VC-viable cells; EA-early apoptosis; LA-late apoptosis; N-necrosis.

\begin{tabular}{cccccc}
\hline & & VC & EA & LA & N \\
\hline \multirow{3}{*}{$3 \mathrm{~h}$} & untreated cells & $96.5 \pm 0.19$ & $3.4 \pm 0.26$ & $0.1 \pm 0.13$ & \\
& leaf extract & $83.3 \pm 1.37$ & $16.4 \pm 1.34$ & $0.2 \pm 0.09$ & $0.1 \pm 0.08$ \\
& fruit extract & $80.0 \pm 4.14$ & $16.1 \pm 4.48$ & $3.1 \pm 0.23$ & $0.7 \pm 0.1$ \\
& untreated cells & $87.3 \pm 7.09$ & $12.7 \pm 0.28$ & $0.1 \pm 0.105$ & - \\
$6 \mathrm{~h}$ & leaf extract & $74.4 \pm 3.53$ & $25.2 \pm 3.59$ & $0.4 \pm 0.027$ & - \\
& fruit extract & $77.0 \pm 6.11$ & $22.9 \pm 6.10$ & - & - \\
& untreated cells & $90.9 \pm 0.08$ & $8.7 \pm 0.215$ & $0.4 \pm 0.29$ & - \\
\multirow{3}{*}{$12 \mathrm{~h}$} & leaf extract & $56.1 \pm 2.08$ & $41.3 \pm 2.48$ & $2.5 \pm 1.57$ & $0.1 \pm 0.07$ \\
& fruit extract & $73.6 \pm 4.78$ & $25.9 \pm 4.71$ & $0.2 \pm 0.17$ & $0.1 \pm 0.06$ \\
& untreated cells & $96.3 \pm 0.38$ & $2.2 \pm 0.10$ & $1.4 \pm 0.29$ & - \\
& leaf extract & $52.5 \pm 2.10$ & $45.7 \pm 2.47$ & $1.9 \pm 0.36$ & - \\
& fruit extract & $53.2 \pm 3.85$ & $45.6 \pm 4.52$ & $1.2 \pm 0.66$ & - \\
& untreated cells & $97.1 \pm 3.58$ & $2.9 \pm 2.15$ & - & - \\
& leaf extract & $68.3 \pm 2.59$ & $29.4 \pm 1.87$ & $2.3 \pm 0.35$ & - \\
& fruit extract & $71.9 \pm 1.13$ & $21.8 \pm 0.98$ & $1.2 \pm 1.01$ & $3.1 \pm 0.15$ \\
\hline
\end{tabular}


The AO/EB and the MTT assays showed similar time-dependent effects on viability but the percent of viabilities were different. In MTT assays absorbance of control cells were considered as $100 \%$ and percentages of viable cells were calculated as ratio to the control, while in $\mathrm{AO} / \mathrm{EB}$ assay percentages of viable cells are real numbers, calculated as ratio to the total number of cells in treatment. If there is a difference in viability it is because mitochondrial function assays (MTT) detected cell death earlier than others, while apoptosis indicating assays (AO/EB) detected cell death later in the process, which is in correlation with other data [18].

According to obtained results we can conclude that $L$. vulgare has antiproliferative properties which increase with exposure time up to $24 \mathrm{~h}$, when extracts have the best activity. The methanolic leaf extract has better antiproliferative activity than the methanolic fruit extract with lower $\mathrm{IC}_{50}$ values, and induces a higher percentage of apoptotic cells after $12 \mathrm{~h}$ of exposure. Extracts were able to induce cell apoptosis, but they did not induce necrosis in HCT-116 cells. Necrotic cells appeared in a very small percentage.

The mechanism of action is unclear and, possibly, multiple compounds in the herbal extracts are involved [19]. Plant-derived chemical constituents, flavonoids, iridoids, coumarins, phenyl propanes and essential oil were reported to be the main constituents in L. vulgare but which are responsible for biological activities is not known [20].

\subsection{Antiproliferative Effects of L. vulgare Extracts in co-Treatment with Pd(apox) Complex}

Cancer is the third leading cause of death worldwide, preceded by cardiovascular and infectious diseases. There are standard chemotherapeutic drugs for treatment of cancers. Several studies have shown that chemotherapeutic drugs have harmful effects on health and can lead to the development of drug resistance in tumor cells, which limit the clinical success of cancer chemotherapy [21,22]. Recent reports show that chemotherapeutic drugs and natural compounds with known anti-cancer activity could be used in combination therapy to reduce the systemic toxicity of chemotherapeutic agents $[23,24]$. So-called natural compounds with anti-cancer activity often modify many intracellular signaling pathways simultaneously. Previous reports demonstrated that many side effects of common used chemotherapy agents are consequences of induction of oxidative stress, which could be palliated by antioxidant food and plants [25].

In this study, the antiproliferative and proapoptotic activity of the methanolic extracts of L. vulgare and the chemotherapeutic drug-Pd(apox) complex were investigated in HCT-116 cells by MTT cell viability assay and $\mathrm{AO} / \mathrm{EB}$ assay. Different combinations of $\mathrm{Pd}(\mathrm{apox})$ and plant extracts were used to find those combinations showing the highest potential to reduce viability of HCT-116 cells. Combination assays were performed using appropriate concentrations of methanolic extracts of L. vulgare (1,50,100 and $250 \mu \mathrm{g} / \mathrm{mL})$ with appropriate concentrations of $\operatorname{Pd}($ apox $)$ complex (100 and $250 \mu \mathrm{M}$ ). The $\mathrm{Pd}$ (apox) complex was added after 3, 6 and $24 \mathrm{~h}$ of cell incubation with plant extract. Cell viability was measured after $24 \mathrm{~h}$ (for cells where Pd(apox) was added after 3 and $6 \mathrm{~h}$ of cell exposure to plant extracts) and after $72 \mathrm{~h}$ (for cells where Pd(apox) was added after $24 \mathrm{~h}$ of cell exposure to plant extracts). Cells treated with the same final concentrations of the extracts or chemotherapeutic drugs alone were also examined. 
The MTT assay indicated that the $\operatorname{Pd}($ apox) complex had very weak antiproliferative activity

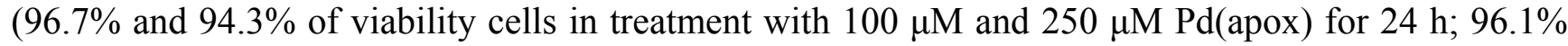
and $91.3 \%$ of viability cells in treatment with $100 \mu \mathrm{M}$ and $250 \mu \mathrm{M} \operatorname{Pd}($ apox) for $72 \mathrm{~h}$ ). Literature data also imply that palladium compounds are not stable and therefore in the cellular environment will be translabilized easily by other biomolecules such as GSH, giving intermediates [26].

L. vulgare extracts were selectively toxic against HCT-116 cell line over different time periods, and in combination with $\mathrm{Pd}($ apox) complex produced an increased growth inhibitory effect (Figures 3 and 4) with lower $\mathrm{IC}_{50}$ values (Table 3 ). The addition of $\mathrm{Pd}$ (apox) complex significantly reduces the $\mathrm{IC}_{50}$ values (calculated in relation to the concentration of plant extract), although Pd (in individual treatment) did not show antiproliferative activity. The best antiproliferative activity was observed with the combination of leaf extract and $250 \mu \mathrm{M}$ Pd(apox) complex measured after $72 \mathrm{~h}\left(\mathrm{IC}_{50}=4.8 \pm 0.6\right.$ ). The results indicate that $\operatorname{Pd}($ apox) complex and plant extracts have synergistic effects on cell proliferation inhibition.

Figure 3. Antiproliferative activity of methanolic leaf extract of $L$. vulgare alone and in combinations with Pd(apox) complex on HCT-116 cell line. Cells were treated with plant extracts and after 3, 6 and $24 \mathrm{~h}$ of incubation $\mathrm{Pd}($ apox) complex was added. The antiproliferative activity was measured by MTT assay after $24 \mathrm{~h}$ (1 and 2) and $72 \mathrm{~h}$ (3) of initial treatment with plant extracts. Results were expressed as means \pm SE for three independent determinations.

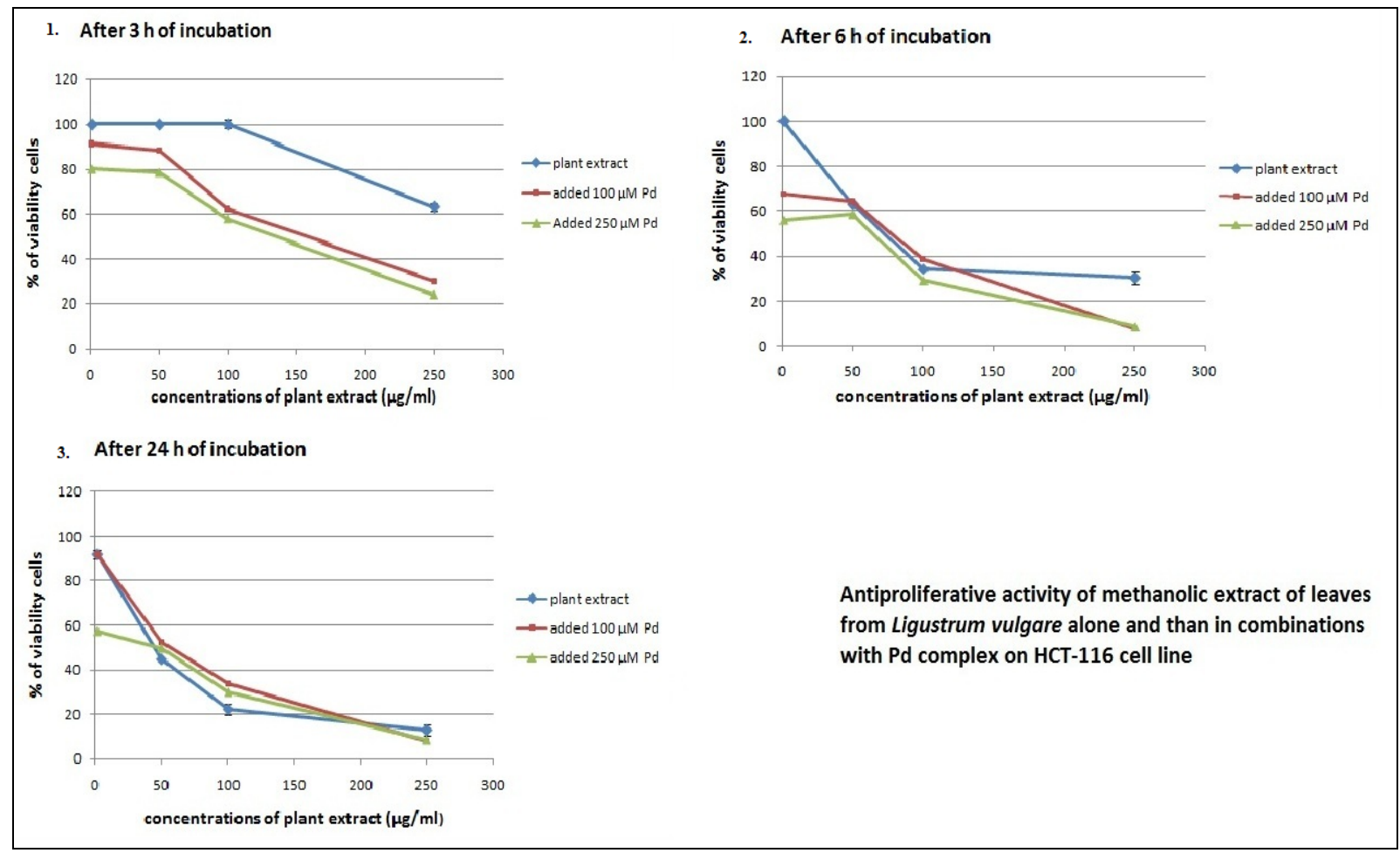


Figure 4. Antiproliferative activity of methanolic fruit extract of $L$. vulgare alone and in combinations with Pd(apox) complex on HCT-116 cell line. Cells were treated with plant extracts and after 3, 6 and $24 \mathrm{~h}$ of incubation $\mathrm{Pd}($ apox) complex was added. The antiproliferative activity was measured by MTT assay after $24 \mathrm{~h} \mathrm{(1} \mathrm{and} \mathrm{2)} \mathrm{and} 72 \mathrm{~h}$ (3) of initial treatment with plant extracts. Results were expressed as means \pm SE for three independent determinations.

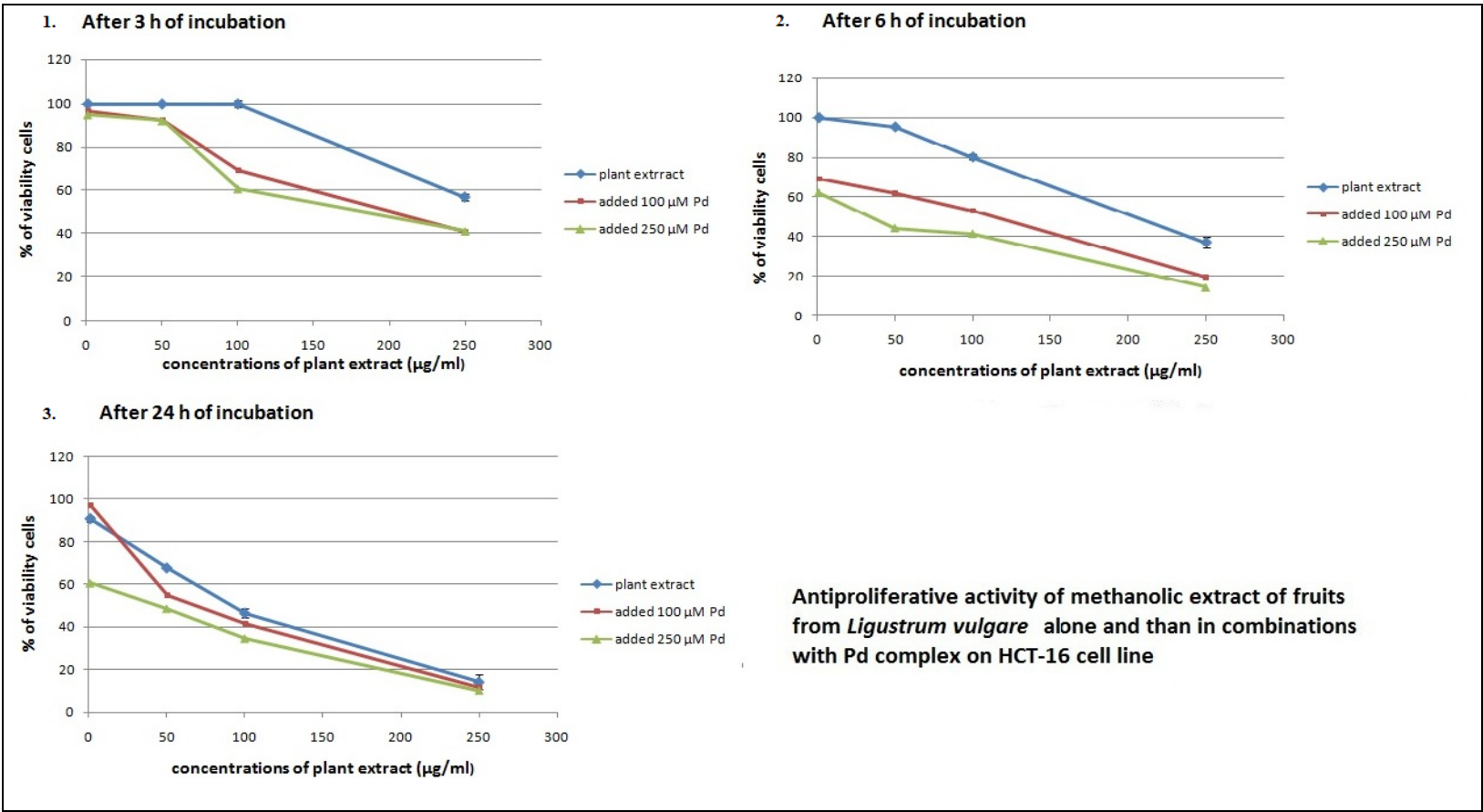

Table 3. Growth inhibitory effects- $-\mathrm{IC}_{50}$ values $(\mu \mathrm{g} / \mathrm{mL})$ of methanolic leaf and fruit extracts of L. vulgare in combination with Pd(apox) complex on HCT-116 cell line. $\mathrm{IC}_{50}$ values was calculated in relation to the concentration of plant extract. Cells were treated with plant extracts and after 3, 6 and $24 \mathrm{~h}$ of incubation $\operatorname{Pd}($ apox) complex was added. The antiproliferative activities were measured by MTT assay after 24 and $72 \mathrm{~h}$ of initial treatment with plant extracts. Results were expressed as means \pm SE for three independent determinations.

\begin{tabular}{cccc}
\hline \multirow{2}{*}{$\begin{array}{c}\text { Membination of } \\
\text { drugs }\end{array}$} & $\begin{array}{c}\text { Md(apox) complex added } \\
\text { after } \mathbf{3} \text { h of cell } \\
\text { incubation with plant } \\
\text { extract }\end{array}$ & $\begin{array}{c}\text { Pd(apox) complex } \\
\text { added after } \mathbf{6} \text { h of cell } \\
\text { incubation with plant } \\
\text { extract }\end{array}$ & $\begin{array}{c}\text { Pd(apox) complex added } \\
\text { after } \mathbf{2 4} \mathbf{~ h} \text { of cell } \\
\text { incubation with plant } \\
\text { extract }\end{array}$ \\
\hline $\begin{array}{c}\text { Leaf extract and } \\
100 \mu \mathrm{M} \mathrm{Pd}\end{array}$ & $269.5 \pm 2.89$ & $13.8 \pm 1.21$ & $27.1 \pm 1.47$ \\
$\begin{array}{c}\text { Leaf extract and } \\
250 \mu \mathrm{M} \mathrm{Pd}\end{array}$ & $121.1 \pm 3.25$ & $5.5 \pm 0.75$ & $4.8 \pm 0.65$ \\
$\begin{array}{c}\text { Fruit extract and } \\
100 \mu \mathrm{M} \text { Pd }\end{array}$ & $347.9 \pm 4.63$ & $33.5 \pm 1.56$ & $145.4 \pm 1.26$ \\
$\begin{array}{c}\text { Fruit extract and } \\
250 \mu \mathrm{M} \text { Pd }\end{array}$ & $422.2 \pm 5.41$ & $8.1 \pm 1.01$ & $6.0 \pm 0.25$ \\
\hline
\end{tabular}


Similar viability results for $\mathrm{Pd}$ (apox) complex were obtained from the $\mathrm{AO} / \mathrm{EB}$ assay $(96.9 \%$ and $94.9 \%$ of viability cells in treatment with $100 \mu \mathrm{M}$ and $250 \mu \mathrm{M} \mathrm{Pd}$ (apox) for $24 \mathrm{~h} ; 96.7 \%$ and $92.7 \%$ of viability cells in treatment with $100 \mu \mathrm{M}$ and $250 \mu \mathrm{M} \operatorname{Pd}($ apox) for $72 \mathrm{~h}$ ). Table 4 summarizes the percentages of viable, apoptotic and necrotic cells observed by addition of the $\operatorname{Pd}($ apox) complex in combination with plant extracts over different time periods. A time-dependent increase in induction of apoptosis was also observed. The HCT-116 treated with different drug combinations showed an increase in the percentage of early apoptotic cells (combination of methanolic leaf extract of L. vulgare and $250 \mu \mathrm{M} \operatorname{Pd}($ apox) complex: 45.2\%, after $6 \mathrm{~h}$ showed the higest increase of early apoptotic cells), and increased the percentage of late apoptotic cells (the highest increase showed with the combination of methanolic leaf extract of $L$. vulgare and $250 \mu \mathrm{M}$ Pd(apox) complex, after $72 \mathrm{~h}$ ).

Table 4. Different values of viable, apoptotic and necrotic cells as percentage of all cells measured by $\mathrm{AO} / \mathrm{EB}$ fluorescence staining. Cells were treated with $100 \mu \mathrm{g} / \mathrm{mL}$ plant extracts and after 3, 6 and $24 \mathrm{~h}$ of incubation $\mathrm{Pd}$ (apox) complex was added. The cell percentages were measured after 24 and $72 \mathrm{~h}$ of initial treatment with plant extracts. Results were expressed as means $\pm \mathrm{SE}$ for three independent determinations. VC-viable cells; EA-early apoptosis; LA-late apoptosis; N-necrosis.

\begin{tabular}{|c|c|c|c|c|c|}
\hline Time of cell counting & & $\mathrm{VC}$ & EA & LA & $\mathbf{N}$ \\
\hline after $24 \mathrm{~h}$ & control, untreated & $96.3 \pm 0.38$ & $2.2 \pm 0.10$ & $1.4 \pm 0.29$ & - \\
\hline after $72 \mathrm{~h}$ & cells & $97.1 \pm 3.58$ & $2.9 \pm 2.15$ & - & - \\
\hline \multirow{2}{*}{$24 \mathrm{~h}$ after treatment } & $\begin{array}{c}100 \mu \mathrm{M} \mathrm{Pd}(\text { apox }) \\
\text { complex }\end{array}$ & $98.1 \pm 0.89$ & $1.9 \pm 0.28$ & - & - \\
\hline & $\begin{array}{c}250 \mu \mathrm{M} \text { Pd(apox) } \\
\text { complex }\end{array}$ & $96.6 \pm 3.81$ & $3.4 \pm 1.09$ & - & - \\
\hline Pd(apox) complex & combination of drugs & & & & \\
\hline \multirow{8}{*}{$\begin{array}{l}24 \mathrm{~h} \text { after } \\
\text { initial } \\
\text { treatment } \\
\text { with plant } \\
\text { extracts }\end{array}$} & $\begin{array}{c}\text { leaf extract and } \\
100 \mu \mathrm{M} \mathrm{Pd}\end{array}$ & $74.1 \pm 0.93$ & $25.7 \pm 0.47$ & $0.2 \pm 0.29$ & - \\
\hline & $\begin{array}{c}\text { leaf extract and } \\
250 \mu \mathrm{M} \mathrm{Pd}\end{array}$ & $62.3 \pm 6.35$ & $36.5 \pm 4.39$ & $1.1 \pm 0.39$ & - \\
\hline & $\begin{array}{l}\text { fruit extract and } \\
100 \mu \mathrm{M} \mathrm{Pd}\end{array}$ & $79.1 \pm 0.77$ & $20.7 \pm 1.24$ & $0.2 \pm 0.74$ & - \\
\hline & $\begin{array}{l}\text { fruit extract and } \\
\qquad 250 \mu \mathrm{M} \mathrm{Pd}\end{array}$ & $68.9 \pm 4.05$ & $31.1 \pm 1.87$ & - & - \\
\hline & $\begin{array}{l}\text { leaf extract and } \\
100 \mu \mathrm{M} \mathrm{Pd}\end{array}$ & $44.9 \pm 4.76$ & $41.1 \pm 0.79$ & $13.7 \pm 1.25$ & $0.2 \pm 2.56$ \\
\hline & $\begin{array}{l}\text { leaf extract and } \\
250 \mu \mathrm{M} \mathrm{Pd}\end{array}$ & $32.1 \pm 2.68$ & $45.2 \pm 5.05$ & $20.8 \pm 1.74$ & $1.8 \pm 3.21$ \\
\hline & $\begin{array}{l}\text { fruit extract and } \\
100 \mu \mathrm{M} \mathrm{Pd}\end{array}$ & $59.1 \pm 1.57$ & $32.7 \pm 0.41$ & $8.2 \pm 1.13$ & - \\
\hline & $\begin{array}{c}\text { fruit extract and } 250 \\
\mu \mathrm{M} \mathrm{Pd}\end{array}$ & $50.1 \pm 2.91$ & $39.7 \pm 2.31$ & $10.1 \pm 2.01$ & - \\
\hline \multirow{4}{*}{$\begin{array}{l}72 \mathrm{~h} \text { after } \\
\text { initial } \\
\text { treatment } \\
\text { with plant } \\
\text { extracts }\end{array}$} & $\begin{array}{l}\text { leaf extract and } \\
100 \mu \mathrm{M} \mathrm{Pd}\end{array}$ & $37.1 \pm 1.58$ & $26.7 \pm 1.87$ & $34.3 \pm 1.36$ & $1.8 \pm 0.97$ \\
\hline & $\begin{array}{l}\text { leaf extract and } \\
250 \mu \mathrm{M} \mathrm{Pd}\end{array}$ & $30.5 \pm 2.02$ & $29.5 \pm 2.14$ & $37.9 \pm 1.91$ & $2.1 \pm 1.67$ \\
\hline & $\begin{array}{l}\text { fruit extract and } \\
\qquad 100 \mu \mathrm{M} \mathrm{Pd}\end{array}$ & $40.8 \pm 2.14$ & $30.6 \pm 1.57$ & $25.9 \pm 1.36$ & $2.6 \pm 1.07$ \\
\hline & $\begin{array}{l}\text { fruit extract and } \\
250 \mu \mathrm{M} \mathrm{Pd}\end{array}$ & $42.9 \pm 1.64$ & $31.3 \pm 1.42$ & $24.8 \pm 1.42$ & $1.0 \pm 1.34$ \\
\hline
\end{tabular}


It might be possible that $L$. vulgare extracts could induce reactive oxygen species (ROS) in the induction of apoptosis. The ROS production were confirmed for some components from L. vulgare such as flavonoids, terpenoids and other components [27,28]. These findings suggest that L. vulgare extracts could induce apoptosis in HCT-116 cells may be by a ROS mediated mechanism and inhibit the glutathione conjugate export pump. Also the extracts could increase the sensitivity of HCT-116 cells to $\operatorname{Pd}($ apox) complex. As a result, the sensitivity of tumor cells to anticancer drugs was increased [29,30]. The explanation of all the aspects and mechanism of the synergistic effects of L. vulgare extracts and $\mathrm{Pd}($ apox) complex will be the next step in our investigation of this problem.

\section{Experimental Section}

\subsection{Chemicals}

Methanol was purchased from “Zorka pharma”, Serbia. Dublecco's Modified Eagle Medium (DMEM) was obtained from GIBCO, Invitrogen, USA. Fetal bovine serum (FBS) and trypsin-EDTA were from PAA (The cell culture company), Austria. Acridine orange was obtained from Acros organic, New Jersey, USA. Dimethyl sulfoxide (DMSO), ethidium bromide and 3-[4,5-dimethylthiazol-2-yl]-2,5diphenyltetrazolium bromide (MTT) were obtained from SERVA, Germany. The ligand N,N'-bis(3aminopropy1)oxamide $\left(\mathrm{H}_{2}\right.$ apox $)$ was synthesized by following the procedures described in the literature. Potassium tetrachloro-paladate(II) was purchased from Aldrich and used as supplied. Reagent grade, commercially available, chemicals were used without further purification.

\subsection{Preparation of [Pd(apox)]}

Of the ligand $\mathrm{H}_{2}$ apox( $N, N^{\prime}$-bis(3-aminopropyl)oxamide) [31] $0.303 \mathrm{~g}$ was dissolved in $5 \mathrm{~cm}^{3}$ of water and then $0.163 \mathrm{~g}$ of $\mathrm{K}_{2} \mathrm{PdCI}_{4}$ was added slowly to the stirred solution. The $\mathrm{pH}$ of solution in the course of the addition of $\mathrm{K}_{2} \mathrm{PdCI}_{4}$ was kept approximately neutral by addition of $\mathrm{KOH}$ solution. The resulting solution was filtered and then allowed to stand at room temperature. Yellow crystals were obtained. Analytical calculation for $\mathrm{C}_{8} \mathrm{H}_{16} \mathrm{~N}_{4} \mathrm{O}_{2} \mathrm{Pd}$ : C, 31.33; H, 5.26; N, 18.27. Found: C, 31.02; H, $5.33 ; \mathrm{N}, 17.98$.

\subsection{Preparation of Plant Extracts}

Prepared plant material (10 g) was transferred to dark-coloured flasks. It was soaked in $200 \mathrm{~mL}$ of methanol and stored at room temperature. After $24 \mathrm{~h}$, the infusions were filtered through Whatman No. 1 filter paper and the residue was re-extracted with equal volume of solvents. After $48 \mathrm{~h}$, the process was repeated. Combined supernatants were evaporated to dryness under vacuum at $40{ }^{\circ} \mathrm{C}$ using a Rotary evaporator. The obtained extracts were kept in sterile sample tubes and stored in a refrigerator at $4{ }^{\circ} \mathrm{C}$.

\subsection{Cell Preparation, Culturing and Treatments}

HCT-116 cell line was obtained from American Type Culture Collection. Cells were maintained in DMEM supplemented with $10 \%$ Fetal Bovine Serum, with 100 units $/ \mathrm{mL}$ penicillin and $100 \mu \mathrm{g} / \mathrm{mL}$ 
streptomycin. Cells were cultured in a humidified atmosphere with $5 \% \mathrm{CO}_{2}$ at $37{ }^{\circ} \mathrm{C}$. Cells were grown in $75 \mathrm{~cm}^{2}$ culture bottles supplied with $15 \mathrm{~mL}$ DMEM, and after a few passages, cells were seeded in a 96-well plate. The experiments were done at 70 to $80 \%$ confluence.

HCT-116 cells were seeded in a 96-well plate (10,000 cells/well). After $24 \mathrm{~h}$ of cells incubation, the medium was replaced with $100 \mu \mathrm{L}$ medium containing methanolic leaf and fruit extracts of L. vulgare at different concentrations $(1,10,50,100,250$ and $500 \mu \mathrm{g} / \mathrm{mL})$. Untreated cells served as controls. For determination of time dependence, cell viability was determined by MTT assay and type of cell death was determined by $\mathrm{AO} / \mathrm{EB}$ assay under a fluorescent microscope after appropriate incubation times with plant extracts $(3,6,12,24$ and $72 \mathrm{~h})$.

For investigation of combination effects of plant extracts and $\mathrm{Pd}($ apox) complex on cell proliferation, 10,000 cells/well were seeded in 96-well plates. After $24 \mathrm{~h}$ the cells were exposed to four concentrations of methanolic leaf and fruit extracts of $L$. vulgare (1, 50, 100 and $250 \mu \mathrm{g} / \mathrm{mL}) \cdot \operatorname{Pd}($ apox $)$ complex (100 and $250 \mu \mathrm{M})$ was added after 3, 6 and $24 \mathrm{~h}$ of cell incubation with plant extracts. Absorbance was measured and cells were counted after $24 \mathrm{~h}$ (for cells where Pd(apox) was added after 3 and $6 \mathrm{~h}$ of cell exposure to plant extracts) and $72 \mathrm{~h}$ (for cells where Pd(apox) was added after $24 \mathrm{~h}$ of cell exposure to plant extracts) from initial treatments with plants. AO/EB assay for analysis of cell death was also used over the same time intervals and the same combinations of concentrations. Cells were also treated with $\mathrm{Pd}($ apox) complex $(100$ and $250 \mu \mathrm{M})$ alone.

\subsection{Cell Viability Assay (MTT Assay)}

The cell viability was determined by MTT assay [32]. The proliferation test is based on the color reaction of mitochondrial dehydrogenase in living cells by MTT. At the end of the treatment period, MTT (final concentration $5 \mathrm{mg} / \mathrm{mL}$ PBS) was added to each well, which was then incubated at $37{ }^{\circ} \mathrm{C}$ in 5\% $\mathrm{CO}_{2}$ for $2-4 \mathrm{~h}$. The colored crystals of produced formazan were dissolved in $150 \mu \mathrm{L} \mathrm{DMSO}$. The absorbance was measured at $570 \mathrm{~nm}$ on a Microplate Reader. Cell proliferation was calculated as the ratio of absorbance of the treated group divided by the absorbance of the control group, multiplied by 100 to give a percentage proliferation.

\subsection{Fluorescence Microscopic Analysis of Cell Death}

We used acridine orange/ethidium bromide (AO/EB) double staining assay [33]. Acridine orange is taken up by both viable and nonviable cells and emits green fluorescence if interrelated into double stranded nucleic acid (DNA) or red fluorescence if bound to single stranded nucleic acid (RNA). Ethidium bromide is taken up only by nonviable cells and emits red fluorescence by intercalation into DNA. We distinguished four types of cells according to the fluorescence emission and the morphological aspect of chromatin condensation in the stained nuclei. Viable cells have uniform bright green nuclei with an organized structure. Early apoptotic cells (which still have intact membranes but have started to undergo DNA cleavage) have green nuclei, but perinuclear chromatin condensation is visible as bright green patches or fragments. Late apoptotic cells have orange to red nuclei with condensed or fragmented chromatin. Necrotic cells have uniformly orange to red nuclei with a condensed structure. The amount of $20 \mu \mathrm{L}$ of dye mixture $(10 \mu \mathrm{L} / \mathrm{mg}$ AO and $10 \mu \mathrm{L} / \mathrm{mg} \mathrm{EB}$ in distilled water) was mixed with $100 \mu \mathrm{L}$ cell suspension $(10,000$ cells $/ \mathrm{mL})$ in a 96 -well plate. After the 
incubation times with the drugs the suspension was immediately examined and viewed under a Nikon inverted fluorescent microscope (Ti-Eclipse) at 400× magnification. We observed untreated cells as controls. A minimum of 300 cells was counted in each sample. Results were expressed as means $\pm \mathrm{SE}$ for three independent determinations.

\subsection{Statistical Analysis}

The data are expressed as means \pm standard errors (SE). Biological activity was examined in three individual experiments, performed in triplicate for each dose. Statistical significance was determined using the Student's $t$-test or the one-way ANOVA test for multiple comparisons. A $p$ value $<0.05$ was considered as significant. The magnitude of correlation between variables was done using a SPSS (Chicago, IL) statistical software package (SPSS for Windows, ver. 17, 2008). The $\mathrm{IC}_{50}$ values were calculated from the dose curves by a computer program (CalcuSyn).

\section{Conclusions}

The study concludes that $L$. vulgare might be considered as a potential source of metabolites which could be developed as precursors for anti-cancer drugs. There is/are active constituent(s) in L. vulgare with anti-proliferative effect against HCT-116 cells. It is nessesary in the future to determine the type of constituents with potential activities. Isolation, purification and consideration of possible applications of these active compounds are in prospect.

To summarize, our results demonstrate that methanolic leaf and fruit extracts of L. vulgare had the best antiproliferative and proapototic effects after $24 \mathrm{~h}$ with prolonged exposure being less effective. The extracts from leaves had higher antiproliferative activity (with lower $\mathrm{IC}_{50}$ values) than fruit extracts. Combinations of methanolic extracts of L.vulgare with Pd(apox) complex in HCT-116 cell lines had better antiproliferative effects than either agent alone, with significantly lower $\mathrm{IC}_{50}$ values. Leaf extracts had better synergistic effects with the Pd(apox) complex than fruit extracts. Further studies are needed to assess the underlying mechanisms (e.g., signal transduction pathways) leading to growth inhibition induced by single agents and combinations both in vitro and in vivo. A positive outcome of such studies would increase the efficacy of existing chemotherapies with reduced toxicity to normal tissues in the treatment of human colon cancer.

\section{Acknowledgements}

This investigation was supported by the Ministry of Education and Science of the Republic of Serbia [III41010].

\section{References and Notes}

1. Jovanović, B. Ligustrum. In Flora of Republic of Serbia, 5th ed.; Josifović, M., Ed.; Serbian Academy of Science and Arts: Belgrade, Serbia, 1973; pp. 456-457.

2. Pieroni, A.; Pachaly, P.; Huang, Y.; van Poel, B.; Vlietinck, A.J. Studies on anti-complementary activity of extracts and isolated flavones from Ligustrum vulgare and Phillyrea latifolia leaves (Oleaceae). J. Ethnopharmacol. 2000, 70, 213-217. 
3. Baróniková, S.; Nagy, M.; Grančai, D. Changes in immunomodulatory activity of human mononuclear cells after cultivation with leaf decoctions from the genus Ligustrum L. Phytother. Res. 1999, 13, 692-695.

4. Yim, T.K.; Wu, W.K.; Pak, W.F.; Ko, K.M. Hepatoprotective action in an oleanolic acid-enriched extracts of Ligustrum lucidum fruits is mediated through an enhancement on hepatic glutathione regeneration capacity in mice. Phytother. Res. 2001, 15, 589-592.

5. Jantová, S.; Nagy, M.; Ružeková, L.; Grančai, D. Antibacterial activity of plant extracts from the families Fabaceae, Oleaceae, Philadelphaceae, Rosaceae and Staphyleaceae. Phytother. Res. 2000, 14, 601-603.

6. Andrade-Cetto, A.; Henrich, M. Mexican plants with hypoglycaemic effect used in the treatment of diabetes. J. Ethnopharmacol. 2005, 99, 325-348.

7. Sersen, F.; Mucaji, P.; Grancai, D.; Nagy, M. Antioxidative properties of methanol extracts from leaves and fruits of Ligustrum vulgare L. Acta Facult. Pharm. Univ. Comenianae 2005, 52, 204-209.

8. Jantova, S.; Nagy, M.; Ruzekova, L.; Grancai, D. Cytotoxic activity of plant extracts from the families Fabaceae, Oleaceae, Philadelphaceae, Rosaceae and Staphyleaceae. Phytother. Res. 2001, $15,22-25$.

9. He, Z.D.; Lau, K.M.; But, P.P.; Jiang, R.W.; Dong, H.; Ma, S.C.; Fung, K.P.; Ye, W.C.; Sun, H.D. Antioxidative glycosides from the leaves of Ligustrum robustum. J. Nat. Prod. 2003, 66, 851-854.

10. Cragg, M.G.; Newman, D.J. Plants as a source of anticancer agents. J. Ethopharmacol. 2005, 100, $72-79$.

11. Reddy, L.; Odhav, B.; Bhoola, K. Natural products for cancer prevention: global perspective. Pharmacol. Ther. 2003, 99, 1-13.

12. Houghton, P. The role of plants in traditional medicine and current therapy. J. Alt. Comple. Med. 1995, 1, 131-143.

13. Lippert, B. Cisplatin: Chemistry and Biochemistry of a Leading Anticancer Drug; VHCA \& WileynVCH: Zurich, Switzerland, 1999.

14. Kosmider, B.; Wyszynska, K.; Janik-Spiechowicz, E.; Osiecka, R.; Zyner, E.; Ochocki, J.; Ciesielska, E.; Wasowicz, W. Evaluation of the genotoxicity of cis-bis(3-aminoflavone) dichloroplatinum(II) in comparison with cis-DDP. Mutat. Res. 2004, 558, 93-110.

15. Stanković, M.; Ćurčić, M; Žižić, J.; Topuzović, M.; Solujić, S.; Marković, S. Teucrium plant species as natural sources of novel anticancer compounds: antiproliferative, proapoptotic and antioxidant properties. Int. J. Mol. Sci. 2011, 12, 4190-4205.

16. Kampa, M.; Nifli, A.P.; Notas, G.; Castanas, E. Polyphenols and cancer cell growth. Rev. Physiol. Biochem. Pharmacol. 2007, 159, 79-113.

17. Galati, G.; Teng, S.; Moridani, M.Y.; Chan, T.S.; O’Brien, P.J. Cancer chemoprevention and apoptosis mechanism induced by diatary polyphenolics. Drug Metabol. Drug Interact. 2000, 17, 311-349.

18. Oh, H.; Livingston, R.; Smith, K.; Abrishamian-Garcia, L. Comparative study of the time dependency of cell death assays. MIT Undergranduate Res. J. 2004, 11, 53-62. 
19. Darzynkiewicz, Z.; Traganos, F.; Wu, J.M.; Chen, S. Chinese herbal mixture PC SPES in treatment of prostate cancer (review). Int. J. Oncol. 2000, 17, 729-736.

20. Nagy, M.; Sersen, F. Free radical scavenging activity of different extracts and some constituents from the leaves of Ligustrum vulgare and L. delavayanum. Fitoterapia 2006, 77, 395-397.

21. Von Hoff, D.D.; Layard, M.W.; Basa, P.; Davis, H.L.; Von Hoff, A.L.; Rozencweig, M.; Muggia, F.M. Risk factors for doxorubicininduced congestive heart failure. Ann. Intern. Med. 1979, 91, 710-717.

22. Raghavan, D.; Koczwara, B.; Javle, M. Evolving strategies of cytotoxic chemotherapy for advanced prostate cancer. Eur. J. Cancer 1997, 33, 566-574.

23. Hortobagyi, G.N. Progress in systemic chemotherapy of primary breast cancer: an overview. $J$. Natl. Cancer Inst. Monogr. 2001, 30, 72-79.

24. Tyagi, A.K.; Singh, R.P.; Agarwal, C.; Chan, D.C.; Agarwal, R. Silibinin strongly synergizes human prostate carcinoma DU145 cells to doxorubicin-induced growth Inhibition, G2-Marrest, and apoptosis. Clin. Cancer Res. 2002, 8, 3512-3519.

25. Cetin, R.; Devrim, E.; Kilicoglu, B.; Avci, A.; Candir, O.; Durak, I. Cisplatin impairs antioxidant system and causes oxidation in rat kidney tissues: Possible protective roles of natural antioxidant foods. J. Appl. Toxicol. 2006, 1, 42-46.

26. Keter, F.K. Pyrazole and pyrazolyl palladium(II) and platinum(II) complexes: synthesis and in vitro evaluation as anticancer agents. M.S. Thesis, University of the Western Cape, Cape Town, South Africa, November 2004.

27. Ferguson, P.; Kurowska, E.; Freman, D.; Chambers, A.; Koropatnick, D. A flavonoid fraction from cranberry extract inhibits proliferation of human tumor cell line. J. Natur. 2004, 134, 1529-1535.

28. Robi, T.; Bishayee, A. Terpenoids and brest cancer chemoprevention. Brest cancer Res. Treat. 2009, 115, 223-239.

29. Zhang, K.; Chew, M.; Wong, K.P. Modulation of cisplatin cytotoxcity and cisplatin-induced DNA crosslink in HepG2 cells by regulation of glutatione-related mechanisms. Mol. Pharmacol. 2001, 59, 837-843.

30. Suzuki, T.; Nishio, K.; Tanabe, S. The MRP family anticancer drug metabolism. Curr. Drug Metab. 2001, 2, 368-377.

31. Journauh, Y.; Sletten, J.; Kahn, O. Tunable interaction in p-Oxamido Copper(II) Binuclear Complexes. Inorg. Chem. 1985, 24, 4063-4069.

32. Mosmann, T. Rapid colorimetric assay for cellular growth and survival: application to proliferation and cytotoxicity assays. J. Immunol. Meth. 1983, 65, 55-63.

33. Baskić, D.; Popović, S.; Ristić, P.; Arsenijević, N.N. Analysis of cyclohexamide-induced apoptosis in human leukocytes: Fluorescence microscopy using annexin V/propidium iodide versus acridin orange/ethidium bromide. Cell Biol. Int. 2006, 30, 924-932.

(C) 2012 by the authors; licensee MDPI, Basel, Switzerland. This article is an open access article distributed under the terms and conditions of the Creative Commons Attribution license (http://creativecommons.org/licenses/by/3.0/). 